\title{
Palynostratigraphy of dinosaur footprint-bearing deposits from the Triassic-Jurassic boundary interval of Sweden
}

\author{
VIVI VAJDA ${ }^{1}$, MIKAEL CALNER ${ }^{1}$ and ANDERS AHLBERG ${ }^{2}$
}

Vajda, V., Calner, M. \& Ahlberg, A., 2013: Palynostratigraphy of dinosaur footprint-bearing deposits from the Triassic-Jurassic boundary interval of Sweden. GFF, Vol. 135 (Pt. 1, March), pp. 120-130. (C) Geologiska Föreningen. doi: 10.1080/11035897.2013.799223.

Abstract: The Triassic-Jurassic boundary (c. $200 \mathrm{Ma}$ ) marks one of the five largest Phanerozoic mass extinction events and is characterized by a major turnover in biotas. A palynological study of sedimentary rock slabs bearing dinosaur footprints from Rhaeto-Hettangian strata of Skåne, Sweden was carried out. The theropod dinosaur footprints (Kayentapus soltykovensis) derive from the southern part of the abandoned Vallåkra quarry (Höganäs Formation) and were originally dated as earliest Jurassic (Hettangian) based on lithostratigraphy. Our results reveal that two of the footprints are correlative with the latest Triassic (latest Rhaetian) disaster zone typified by a high abundance of the enigmatic gymnosperm pollen Ricciisporites tuberculatus and Perinopollenites elatoides together with the key taxon Limbosporites lundbladii and fern spores. Two footprints are dated to correlate with the Transitional Spore-spike Interval. One footprint is interpreted as Hettangian in age based on the relatively high abundance of Pinuspollenites spp. together with the presence of the key taxa Retitriletes semimuris and Zebrasporites intercriptus. Our new palynological study suggests that the Kayentapus ichnogenus already appeared in the end of Triassic, and our study highlights the use of palynology as a powerful tool to date historical collections of fossils in museums, universities and elsewhere. The Hettangian footprint reflects a marine influence while all other studied ichnofossil specimens occur in non-marine (floodplain and delta interdistributary) sediments. The sediments associated with the Hettangian footprint include a significant proportion of charcoal transported from land after wildfires. The Rhaeto-Hettangian vegetation was otherwise characterized by multi-storey gymnosperm-pteridophyte communities.

Keywords: Triassic-Jurassic; dinosaur footprints; ecological crisis; palynology; Sweden.

${ }^{1}$ Department of Geology, Lund University, Sölvegatan 12, SE-223 62 Lund, Sweden; vivi.vajda@geol.lu.se

${ }^{2}$ Engineering Education LTH, Lund University, P.O. Box 118, SE-22100 Lund, Sweden

Manuscript received 14 December 2012. Revised manuscript accepted 18 April 2013.

\section{Introduction}

The Triassic-Jurassic ( $\mathrm{Tr}-\mathrm{J}$ ) boundary, dated by $\mathrm{U}-\mathrm{Pb}$ at $201.6 \pm 0.3 \mathrm{Ma}$ (Schaltegger et al. 2008), is marked by a mass extinction of biota in both marine and terrestrial ecosystems (Raup \& Sepkoski 1982; Hallam 2002; Hesselbo et al. 2002, 2007; Andréasson 2006; Ruhl et al. 2009; Akikuni et al. 2010; Deenen et al. 2010; Sha et al. 2011). The causal mechanisms behind this mass extinction remain strongly disputed as its duration, magnitude and geographic signal are not resolved.

Although the signature of extinction in the marine realm is fairly well understood, at least for the northern Hemisphere $\mathrm{Tr}-\mathrm{J}$ successions (Hesselbo et al. 2002, 2007; Götz et al. 2009; Deenen et al. 2010), the magnitude of the extinction and the pattern of recovery in the continental realm are highly ambiguous (Akikuni et al. 2010; Sha et al. 2011; Pieńkowski et al. 2012). Severe changes in the vegetation record across the $\mathrm{Tr}-\mathrm{J}$ boundary have been documented from several parts of the northern Hemisphere, i.e. North America and Greenland (Fowell \& Olsen 1993; Olsen et al. 2002; McElwain et al. 2009; Larsson
2009; van de Schootbrugge et al. 2009; Steinthorsdottir et al. 2011). In the northern European pollen and spore record, this is expressed as a pronounced increase in relative abundance, the so-called spike, of the enigmatic gymnosperm pollen Ricciisporites tuberculatus in uppermost Triassic strata, making this pollen a species of key stratigraphic importance (Pedersen \& Lund 1980; Mander et al. 2013). The species ranges from the Norian to the Sinemurian but has a pronounced acme in the Rhaetian in NW Europe (Pedersen \& Lund 1980; see also Pieńkowski et al. 2012). The botanical affinity of this pollen is not known as it has not been recovered from fossilized reproductive structures (Mander et al. 2012).

The Ricciisporites spike is followed by a fern spore-spike across the boundary interval (Bonis et al. 2009; Götz et al. 2009; Larsson et al. 2009) that has been defined as the Transitional Spore-spike Interval (TSI) based on assemblages from southern Sweden (Larsson 2009) and was recently identified in the latest Rhaetian of Poland (Pieńkowski et al. 2012). The spore-spike is 
generally followed by a Classopollis (Cheirolepidiaceae)dominated flora marking the beginning of the Jurassic, as is the case in Clarence-Moreton and Surat basins of Australia (Jansson et al. 2008a,b; Turner et al. 2009), the Newark Basin, USA (Fowell \& Olsen 1993) and Scandinavia (Guy-Ohlson 1981; Dybkjær 1991). Kuerschner et al. (2007) suggested that the first appearance of Cerebropollenites thiergarti together with a spore-spike marks the $\mathrm{Tr}-\mathrm{J}$ boundary in Austria.

Rhaetian-earliest Jurassic macrofloras of Skåne have been studied for nearly two centuries and are collectively represented by a broad range of bryophytes, lycophytes, sphenophytes, ferns (especially Matoniaceae, Dipteridaceae, Gleicheniaceae, Dicksoniaceae and Osmundaceae), pteridosperms, Bennettitales, Ginkgoales and conifers (Nathorst 1878, 1879; Halle 1908; Johansson 1922; Lundblad 1949, 1950, 1959a; Pott \& McLoughlin 2009, 2011; McLoughlin \& Vajda 2013). Harris (1931) noted a significant disjunction in the composition of the floras across the $\mathrm{Tr}-\mathrm{J}$ boundary in Jameson Land, Greenland, erecting the "Lepidopteris flora" and "Thaumatopteris flora" for what were essentially macrofloral assemblage zones of the Rhaetian and Hettangian, respectively. Lundblad (1959b) applied these concepts to the Skåne $\mathrm{Tr}-\mathrm{J}$ floras and noted $\mathrm{a}$ similar stratigraphic disjunction, with key taxa of Lepidopteris, Ptilozamites, Sphenobaiera, Ginkgoites, Pterophyllum and Anomozamites restricted to the Rhaetian, and Thaumatopteris schenkii restricted to the Jurassic. These floristic differences provide a ready means of differentiating $\mathrm{Tr}-\mathrm{J}$ continental strata in Skåne and signify a major disruption to plant communities at the close of the Triassic that can be recognized globally (Zhou 1995; Anderson et al. 1999).

Large predators were represented in the Late Triassic of Central Europe, contributing to a rich community that included dicynodonts and small dinosauromorphs (Gorzelak et al. 2010; Niedźwiedzki et al. 2012), but only the tracks remain of these in the Tr-J strata in Sweden (Vajda \& Wigforss-Lange 2009). Dinosaur tracks have long been recognized as important sources of palaeontological information in Mesozoic sedimentary deposits globally (e.g. Gierliński \& Ahlberg 1994; Meyer et al. 2001; Turner et al. 2009; Niedźwiedzki 2011; Thulborn 2013). The extinction of non-avian dinosaurs at the CretaceousPaleogene boundary has been the subject of intense debate (Ocampo et al. 2006; Wigforss-Lange et al. 2007; Schulte et al. 2010a,b), but relatively little attention has been given to the dinosaurian response to environmental changes during the endTriassic extinction event (Brusatte et al. 2010). Interestingly, Olsen et al. (2002) noted that non-dinosaurian footprint diversity drops at the $\mathrm{Tr}-\mathrm{J}$ boundary, whereas dinosaurian ichnogeneric diversity increases to a maximum in the overlying Jurassic sediments of the Newark Basin, USA. This coincides with a $20 \%$ increase in theropod dinosaur track size and with the first appearance of Eubrontes giganteus (Olsen et al. 2002). More recent studies have confirmed that the records of theropod and ornithischian dinosaurs markedly increase over the $\mathrm{Tr}-\mathrm{J}$ boundary, indicating a radiation rather than major extinction within these groups (Brusatte et al. 2010).

The Department of Geology, Lund University, Sweden, hosts several dinosaur footprints preserved in clastic sedimentary rock slabs collected primarily during coal and clay exploration in the $20^{\text {th }}$ century (Norin 1949; Gierliński \& Ahlberg 1994). Previous dating of these ichnofossils was based on lithostratigraphical data only; thus, the detailed stratigraphical positions of these ichnofossils are in many cases uncertain. Palynology is a powerful tool for palaeoenvironmental analysis in Mesozoic deposits when applied as changes in relative abundance of different pollen and spore taxa coupled with the presence of key species (Vajda \& Wigforss-Lange 2006; Mehlqvist et al. 2009). Palynology is further useful when dating transported, fossil-bearing concretions and museum specimens of unknown age or provenance (Vajda \& Raine 2010). We use this technique to date the collection of dinosaurian footprints and to reconstruct the vegetation and palaeoenvironment in which these animals lived about 200 million years ago.

\section{Geological setting and stratigraphy}

The Late Triassic-Early Jurassic sedimentary successions in southern Sweden (Skåne) were deposited in areas separated by structural highs, each area reflecting its own depositional and tectonic conditions. These Mesozoic sediments rest disconformably mainly on Palaeozoic strata. In general, tectonic movements along the Fennoscandian Border Zone (Fig. 1) influenced deposition and erosion, leaving unique sedimentary successions and hiatuses in different tectonic blocks (see review by Ahlberg et al. 2003a). $\mathrm{Tr}-\mathrm{J}$ sediments are extensively distributed in the subsurface of the marginal parts of the Danish Basin (southwestern parts of Skåne; Larsson et al. 2000; Vajda 2001, 2008; Fig. 1), whereas outcrops occur mainly in the northwestern and central parts of Skåne. The Norian part of the succession is characterized by barren semi-arid continental redbeds. The onset of regional maritime humidity in the Rhaetian led to deep basement weathering and the development of extensive peat-forming mires in fluvio-deltaic and marginal marine settings. The thick accumulations of Rhaetian siliciclastic strata are rich in plant and animal body and trace fossils (Ahlberg et al. 2002, 2003b).

Exposures of strata spanning the $\mathrm{Tr}-\mathrm{J}$ boundary are located mainly in the north-western Skåne and, in the central parts, along the north-eastern fault zone of the Vomb Trough (Norling 1990; Norling et al. 1993). Palynostratigraphy is the main tool applied for the dating and correlation of these strata. The $\mathrm{Tr}-\mathrm{J}$ boundary beds, of interest here, form part of the Höganäs Formation and are relatively well documented (e.g. Hermelin 1773; Troedsson 1943, 1951; Sivhed 1984; Pieńkowski 1991a,b; Ahlberg et al. 2003a,b; Lindström \& Erlström 2006; Larsson 2009; Vajda \& Wigforss-Lange 2009). The Höganäs Formation comprises mainly alluvial and deltaic sediments and is approximately $250 \mathrm{~m}$ thick. It is subdivided into the Vallåkra, Bjuv and Helsingborg Members (Ahlberg et al. 2003a; Fig. 2). The basal Vallåkra Member consists mainly of mudstones and siltstones, reaching a maximum thickness of $30 \mathrm{~m}$. The overlying heterolithic Bjuv Member incorporates coal seams, palaeosols and crevasse splay sands representing mostly lowenergy floodplain deposits. The two major coals are regionally important markers and are designated the B (lower) and A (upper) seams: the upper surface of the latter has been proposed to mark the Tr-J boundary (Sivhed 1984; Ahlberg et al. 2003b). The uppermost member, the Helsingborg Member, forms the bulk of the Höganäs Formation and constitutes basal Jurassic heterolites, arenites and mudstones with thin coal seams (Ahlberg et al. 2003a). These strata reflect a marginal marine setting and signal the onset of an extended transgression across the Höganäs Basin. 


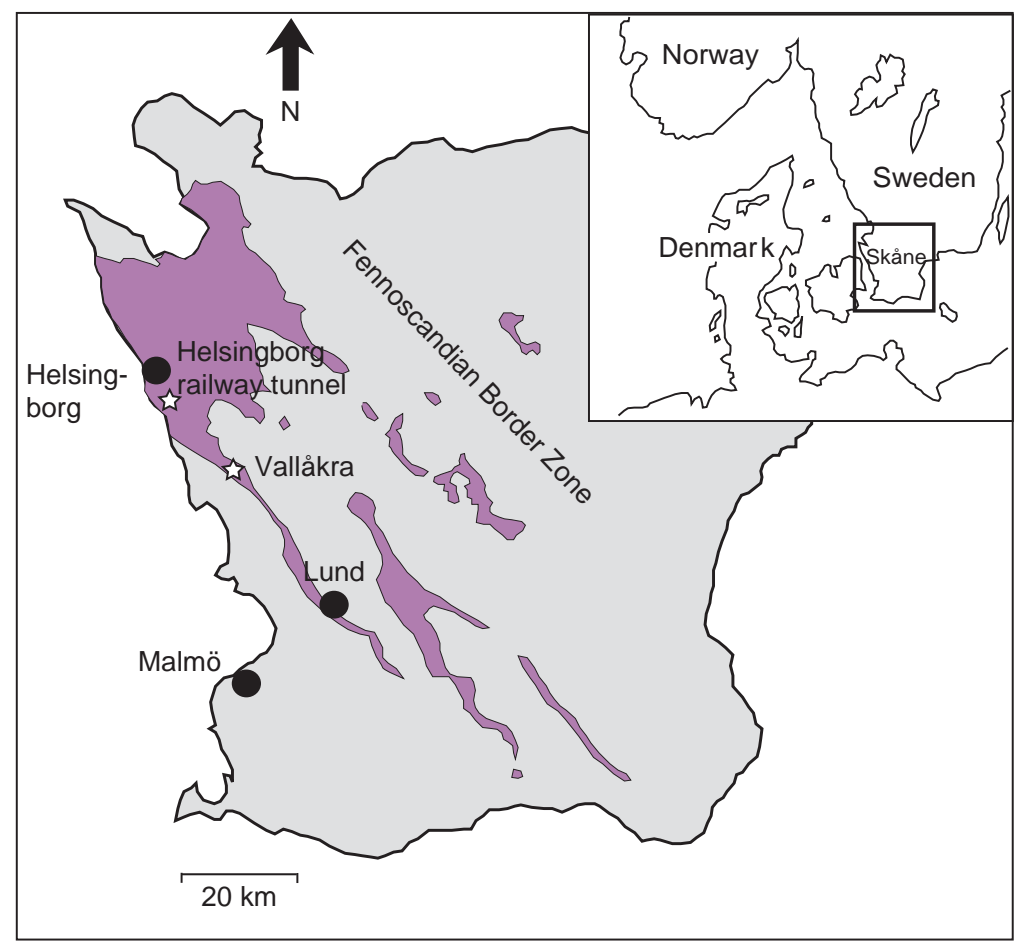

Fig. 1. Geological map of the study area with Sweden inset. Fossil dinosaur track localities marked with star.

\section{Occurrence of dinosaur footprints in Skåne}

Findings of dinosaur footprints in Sweden are rare and restricted to the Höganäs Formation from which four track sites have been described (Gierliński \& Ahlberg 1994). The first footprints were discovered in the early 1950s as the regionally important B-coal seam in the Bjuv Member was excavated in the now inaccessible Gustaf Adolf mine at Höganäs and in the Haberga mine at Billesholm (Bölau 1952; Fig. 1). The numerous tracks, no less than 170 in $45 \mathrm{~m}^{2}$ at one place, were discovered in the roof of the mines as the coal was quarried. Individual tracks measured up to $38 \mathrm{~cm}$ in length and were designated simply as theropod tracks (Bölau 1952). A few of the specimens from the Gustaf Adolf mine were subsequently identified as Eubrontes sp. by Haubold (1986) and as Grallator (Eubrontes) sp. (most specimens) or Grallator (Eubrontes) cf. giganteus (single well-preserved footprint) by Gierliński \& Ahlberg (1994).
The next important finding of dinosaur footprints dates to the mid-1970s, this time in the southern quarry at Vallåkra ("Vallåkra Södra"; Figs. 3 and 4). The strata at this locality were assigned to the early Hettangian Boserup Beds by Sivhed (1984), although its heterolithic facies differ from exposed facies of the fluvial Boserup Beds (Ahlberg et al. 2003a). The ichnofossils at Vallåkra were discovered by members of the Geological Survey of Sweden and named as "Theropodian footprints" by Pleijel (1975). The footprints range in length from 15 to $35 \mathrm{~cm}$ and were found in several beds in the lowermost metre of a 6.4-m thick succession of wavy and lenticularly bedded heteroliths (starved mud-draped sandy ripples) with abundant rootlets and desiccation mud cracks, interpreted as formed in marginal marine, brackish or even freshwater (lake) environments. There is a size variation within the footprint assemblage at Vallåkra that has been interpreted reflecting ontogenetic stages (a pack or herd) (Gierliński \&

\begin{tabular}{|c|c|c|c|c|c|}
\hline \multicolumn{2}{|c|}{ System } & Stage & Formation & Member & Miospore Zone \\
\hline \multirow{5}{*}{ 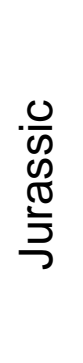 } & \multirow{5}{*}{ 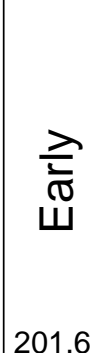 } & Toarcian & \multirow{4}{*}{ Rya Formation } & Rydebäck Member (70) & Spheripollenites-Leptolepidites \\
\hline & & Pliensbachian & & Katslösa Member (40) & Chasmatosporites \\
\hline & & \multirow{2}{*}{ Sinemurian } & & Pankarp Member (70) & \multirow[b]{2}{*}{ C. macroverrucosus } \\
\hline & & & & Döshult Member (80) & \\
\hline & & Hettangian & \multirow{3}{*}{ Höganäs Formation } & Helsingborg Mb & Pinuspollenites-Trachysporites \\
\hline \multirow{3}{*}{ 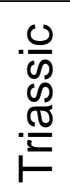 } & \multirow{2}{*}{\multicolumn{2}{|c|}{ Rhaetian }} & & Bjuv Member & Transitional Spore-spike Interval \\
\hline & & & & Vallåkra Member & Corollina - Ricciisporites \\
\hline & \multicolumn{2}{|r|}{ Norian } & \multicolumn{2}{|c|}{ Kågeröd Formation } & Undefined \\
\hline
\end{tabular}

Fig. 2. Stratigraphic column of the Tr-J units of Skåne correlated with local pollen zones (from Koppelhus \& Nielsen 1994; Larsson 2009). 


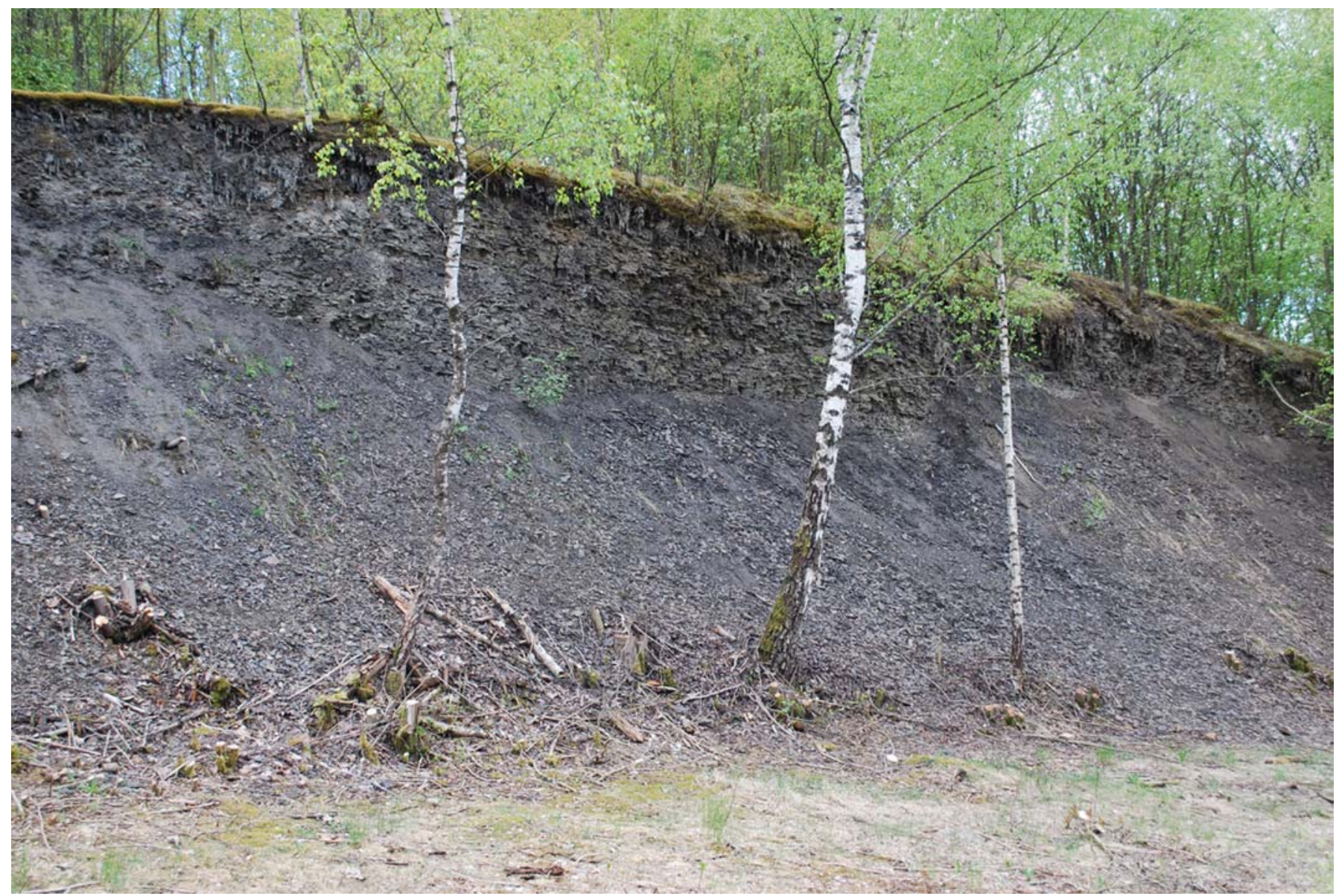

Fig. 3. The southern wall of the Vallåkra "Södra" quarry south-east of Helsingborg, showing mudstone with thin sand partings (heterolitic facies). This locality is the origin for several dinosaur footprints $(\mathrm{G})$ that in this study are dated as latest Rhaetian-earliest Hettangian.

Ahlberg 1994). All specimens from this locality have subsequently been assigned to one single ichnotaxon, namely Grallator(Eubrontes) soltykovensis = Kayentapus soltykovensis (Gierliński \& Ahlberg 1994; see Gierliński 1996).

The most recent find of dinosaur footprints from the Höganäs Formation derives from the early Hettangian strata that were excavated during the construction of the Helsingborg railway tunnel in the late 1980s. The two specimens described there were both assigned to Grallator (Eubrontes) sp. but could not be collected due to construction safety (Ahlberg \& Siverson 1991).

Olsen (1980) argued that most of the Triassic and Lower Jurassic theropod track morphologies represent members of a Grallator-Anchisauripus-Eubrontes plexus, and that ichnologists could use the double-barreled "ichnogenus" labels Grallator (Grallator), Grallator (Anchisauripus) and Grallator (Eubrontes). This ichnosystematic scheme has been accepted by some authors (e.g. Gierliński 1991; Gierliński \& Ahlberg 1994). Finally, Olsen et al. (1998) subsequently abandoned this nomenclature when re-describing the type material of the three theropod dinosaur ichnogenera Grallator, Anchisauripus and Eubrontes as distinct morphotypes. In the Lower Jurassic deposits, the Kayentapus ichnogenus has been identified also in numerous sites in North America and Europe, and has quite consistently been regarded as a distinct ichnogenus (Lockley et al. 2011). Although some dinosaur ichnologists have suggested that Kayentapus might be a synonym of Eubrontes (see Rainforth 2005; Lucas et al. 2006). Kayentapus is the ichnogenus name applied to relatively large (pes length $\sim 25-$ $35 \mathrm{~cm}$ ) tridactyl tracks of a bipedal theropod dinosaur, originally described by Samuel Welles, in 1971, based on a short trackway from the Lower Jurassic Kayenta Formation of Arizona.

\section{Materials and methods}

Five dinosaur ichnofossils from the collection of the Department of Geology in Lund were selected for palynological analysis. Small chips of rock were carefully removed from the specimens without damaging the footprints. The samples were processed according to standard palynological procedures at Global Geolab Limited, Canada. About $30 \mathrm{~g}$ of sediment was first treated with dilute hydrochloric acid to remove calcium carbonate, and further macerated in $45 \%$ hydrofluoric acid. The organic residue was sieved using a 10- $\mu \mathrm{m}$ mesh and mounted in epoxy resin on two microscopic slides. Three hundred pollen and spores were identified per sample and the percentage of each palynomorph taxa was calculated (Appendix A). Palynofacies analysis involved counting the relative abundance of organic particles based on 500 counts per slide. Classification of palynological matter was based on the scheme developed by Batten (1996). The following palynofacies groupings were distinguished: (I) palynomorphs (pollen, spores, acritarchs), (II) wood, (III) charcoal, (IV) plant cuticle and (V) amorphous organic matter (AOM; Fig. 5). The slides and residues are deposited at the Department of Geology at Lund University and illustrated specimens are identified by LO numbers. 


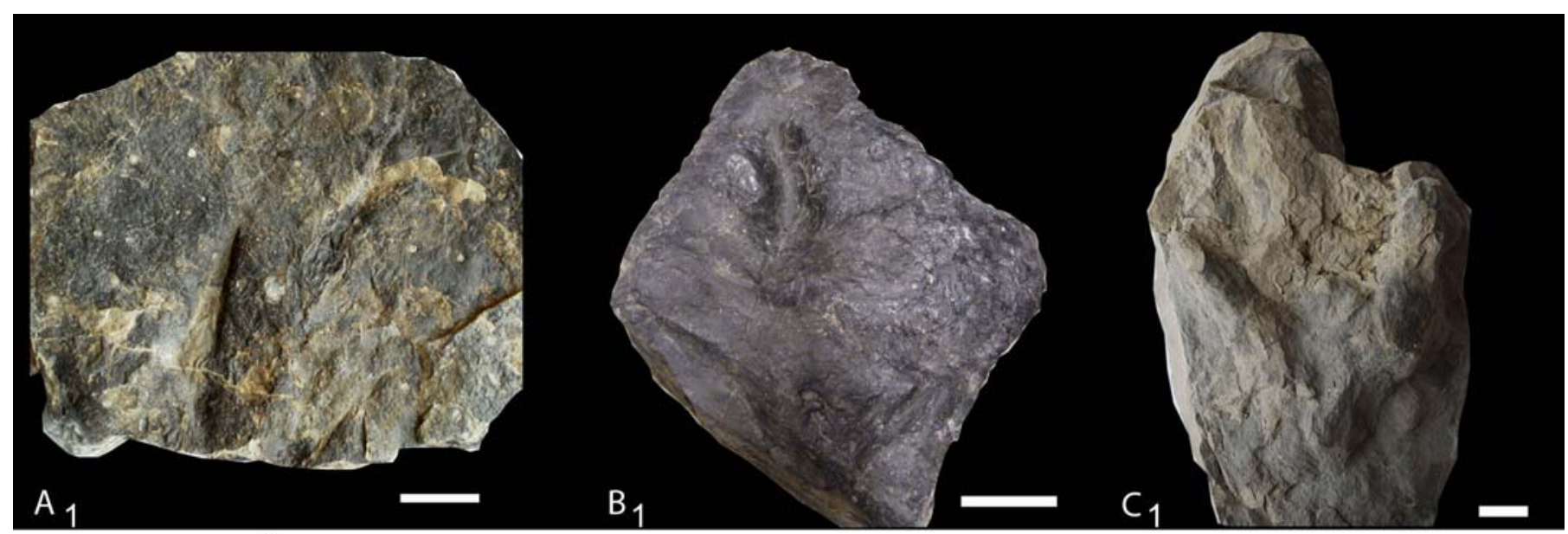

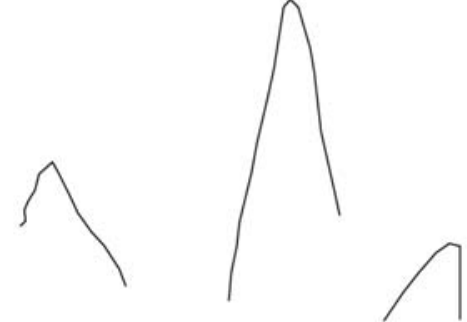

$\mathrm{A}_{2}$

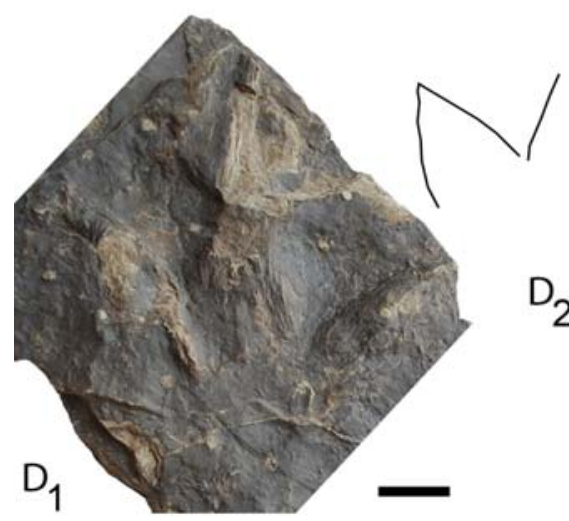

$\mathrm{B}_{2}$

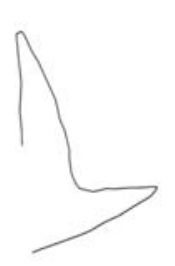

$\mathrm{C}_{2}$
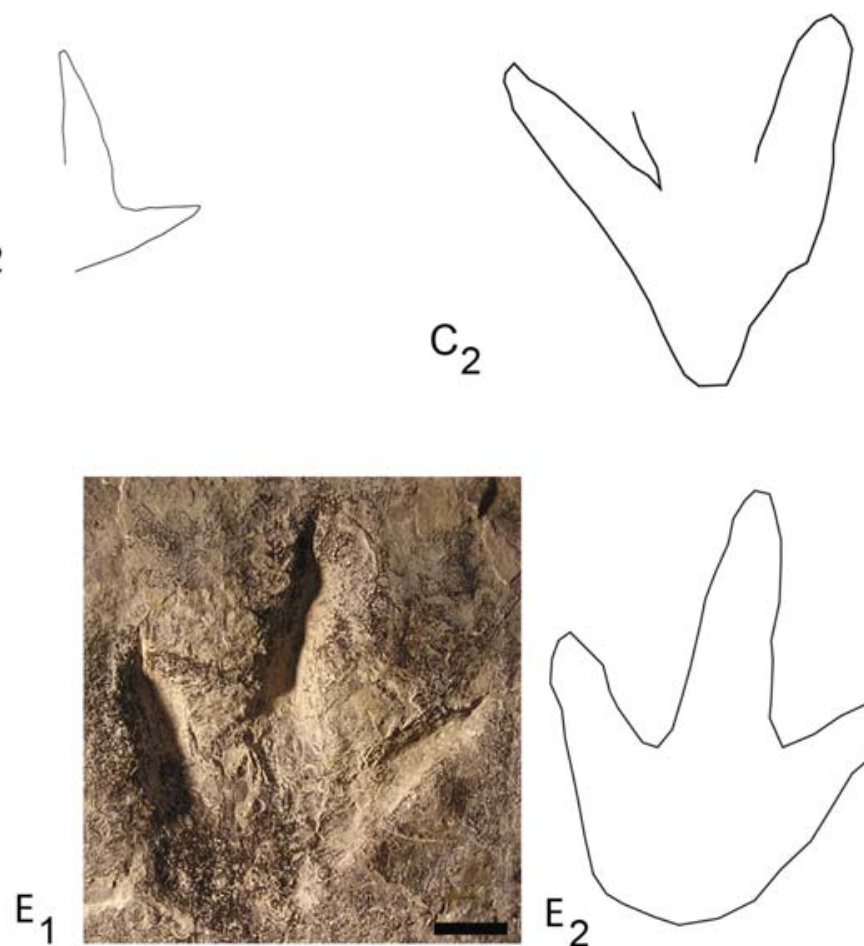

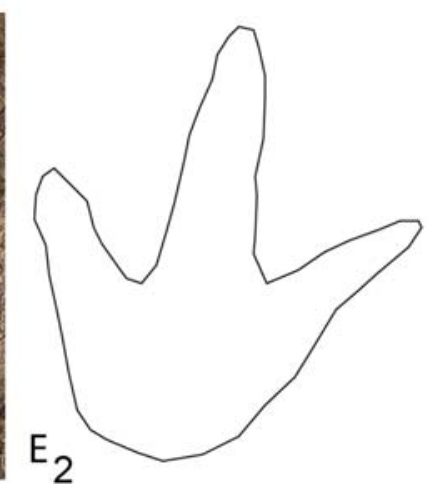

Fig. 4. The five-sampled Tridactyl tracks (pes prints) of G. (E.) soltykovensis Gierliński 1991 ( = K. soltykovensis) (Rhaetian-Hettangian), Sweden. A. Hettangian (LO11768t), B. Rhaetian (LO11769t), C. Rhaetian (11770t), D. Transitional Tr-J boundary (LO11771t), E. Transitional $\mathrm{Tr}-\mathrm{J}$ boundary (LO5463t). Specimens are deposited in the Department of Geology at Lund University. Photographs (A1-E1) and drawings (A2E2). Scale bars $5 \mathrm{~cm}$.

\section{Results}

\section{Sample 1 (LO11768t)}

Ichnofossil $G$. (E.) soltykovensis ( $=$ K. soltykovensis) belonging to a theropod dinosaur set in a light grey siltstone with dark carbonaceous lamina. The footprint was collected from the abandoned Vallåkra quarry (Höganäs Formation). The ichnofossil is preserved as a negative imprint, an epichnia observable as a concave feature on the uppermost bedding plane of the siltstone block. The palynological assemblage recovered from the sediments hosting the ichnofossil is dated to earliest Jurassic (Hettangian).

Palynofacies. - The microscopic organic matter is in this sample dominated by wood remains $(51 \%)$ and charcoalified matter
$(26 \%)$. Pollen and spores together attain a relative abundance of 20\% (Fig. 5A; Table 1).

Palynology. - Within the palynological assemblage of Sample 1, 25 species of pollen and spores were identified (Appendix A). The spores attain $51 \%$ of the assemblage and gymnosperm pollen grains attain $47.5 \%$. In addition, two marine acritarch species were identified, making up $2 \%$ of this otherwise terrestrial assemblage. The spores are dominated by fern spores which in turn are strongly dominated by the trilete spore Cyathidites minor $(36 \%)$, followed by the spores produced by the ground fern Gleicheniidites senonicus. Lycophyte spores reach a relative abundance of $5 \%$, whereas bryophytes spores represent $2 \%$. The gymnosperms are dominated by the enigmatic gymnosperm pollen Ricciisporites with unresolved affinity. Other important 
A.

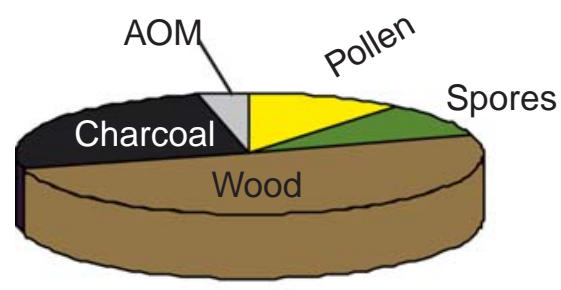

B.

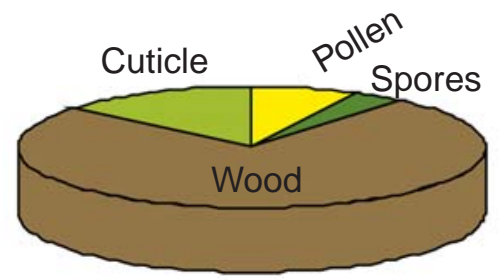

C.

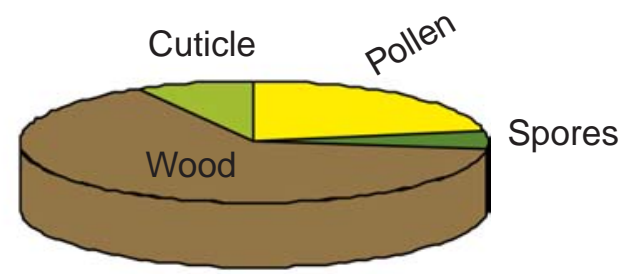

D.

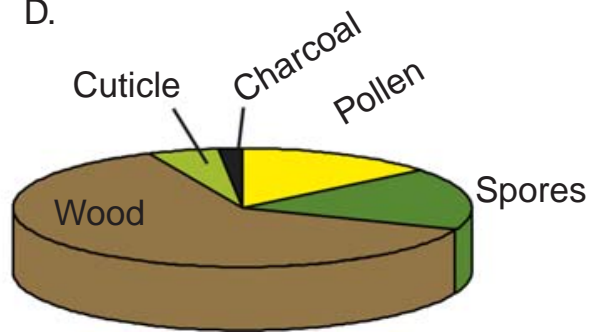

E.

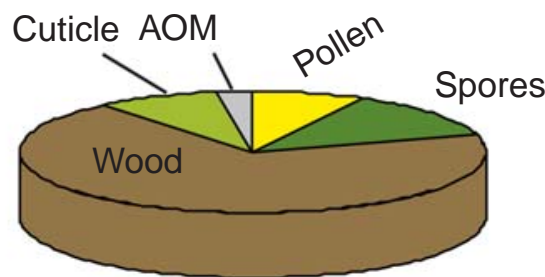

Fig. 5. Graphical representation of the percentages for each palynofacies category for the different samples. A. Footprint 1 (LO11768t), Early Jurassic, Hettangian. B. Footprint 2 (LO11769t), latest Triassic Rhaetian. C. Footprint 3 (LO 11770t), latest Triassic Rhaetian. D. Footprint 4 (LO11771t), transitional Tr-J boundary interval. E. Footprint 5 (LO5463t), transitional Tr-J boundary interval.

gymnosperms include Pinuspollenites (10\%), Perinopollenites elatoides, Alisporites, Classopollis and Quadraeculina anellaeformis (Figs. 6 and 7).

Age. - Important key species occurring in low numbers include Acanthotriletes varius, Striatella seebergensis, Retitriletes semimuris, Zebrasporites intercriptus and Cibotiumspora juriensis, and for the dating, most importantly, Pinuspollenites makes up $10 \%$ of the palynoflora. Based on these characteristics, the age of this footprint is interpreted as earliest Jurassic, Hettangian.

\section{Sample 2 (LO11769t)}

Ichnofossil $G$. (E.) soltykovensis ( $=K$. soltykovensis) belonging to a theropod dinosaur occurring in a carbonaceous mudstone. The footprint was collected from Vallåkra abandoned quarry (Fig. 3) from the Höganäs Formation. Based on the palynological results of this study, these sediments are dated as late Rhaetian.

Palynofacies. - The organic matter in Sample 2 is dominated by wood particles which, together with cuticle remains, represent $89 \%$ of the organic particles; pollen and spores together comprise the remaining 11\% (Fig. 5B; Table 1).

Palynology. - The species diversity is relatively poor and only 12 miospore species were identified in Sample 2 (Appendix A).
The assemblage is entirely terrestrial with no marine palynomorphs identified. Spores comprise $35 \%$ of the assemblage and gymnosperm pollen grains comprise $65 \%$. The gymnosperm pollen grains are dominated by $P$. elatoides (35\%) followed by Ricciisporites (19\%). Other important gymnosperm pollen includes Classopollis and Podocarpidites (Fig. 6; Appendix A). The spores are dominated by ferns (19\%), lycophytes (14\%) and bryophytes (2\%; Appendix A).

Age. - A late Rhaetian age is inferred for this sample based on the relative abundance data showing high portions of $R$. tuberculatus and P. elatoides, together with the presence of the typical Rhaetian key species Limbosporites lundbladii.

\section{Sample $3(11770 t)$}

Ichnofossil $G$. (E.) soltykovensis ( $=K$. soltykovensis) belonging to a theropod dinosaur preserved as a positive-relief hypichnia, observable as a convex feature on the uppermost bedding plane of the light siltstone block. Collected at Vallåkra, southern side of the quarry, Höganäs Formation. Dated to Rhaetian based on the palynological results of this study.

Palynofacies. - The organic residue in Sample 3 is dominated by wood particles $(65 \%)$ and cuticles $(8 \%)$. Pollen and spores reach $26 \%$ together (Fig. $5 \mathrm{C}$; Table 1 ).

Table 1. Percentages of the each palynofacies category representing the different ichnofossil Samples 1-5.

\begin{tabular}{|c|c|c|c|c|c|}
\hline $\begin{array}{l}\text { Ichnofossil } \\
\text { Age }\end{array}$ & $\begin{array}{c}1 \text { (LO11768t) } \\
\text { Hettangian }\end{array}$ & $\begin{array}{c}2(\mathrm{LO} 11769 \mathrm{t}) \\
\text { Rhaetian }\end{array}$ & $\begin{array}{c}3 \text { (LO11770t) } \\
\text { Rhaetian }\end{array}$ & $\begin{array}{c}4 \text { (LO11771t) } \\
\text { Transitional }\end{array}$ & $\begin{array}{l}5 \text { (LO5463t) } \\
\text { Transitional }\end{array}$ \\
\hline \multicolumn{6}{|c|}{ Palynofacies category (\%) } \\
\hline Pollen & 11 & 7 & 22 & 14 & 8 \\
\hline Spores & 9 & 4 & 4 & 17 & 13 \\
\hline Wood & 51 & 75 & 65 & 62 & 68 \\
\hline Cuticles & 0 & 14 & 8 & 5 & 9 \\
\hline Charcoal & 26 & 0 & 0 & 2 & 0 \\
\hline AOM & 4 & 0 & 0 & 0 & 3 \\
\hline
\end{tabular}




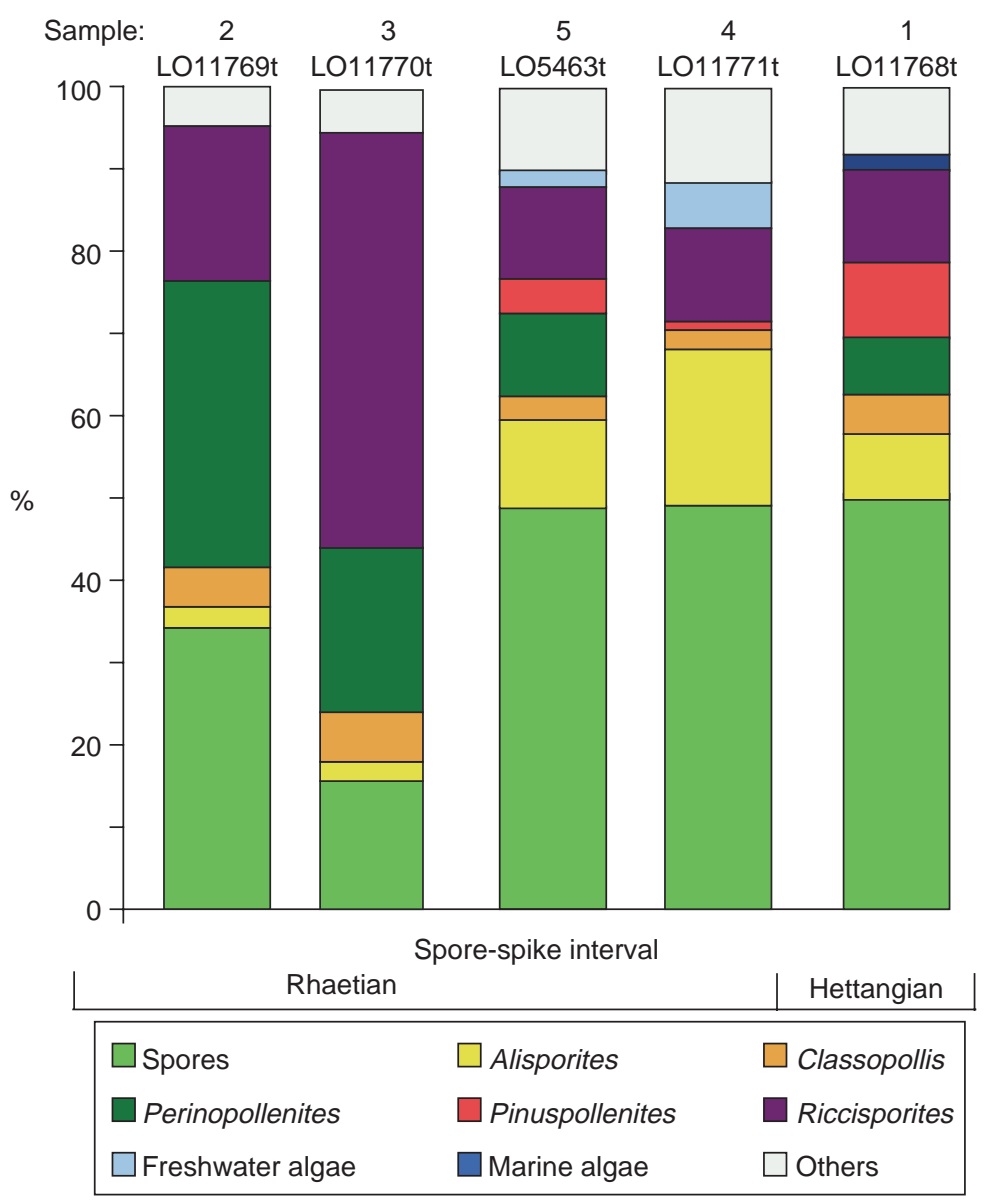

Fig. 6. Relative abundance (\%) of spores, freshwater taxa, marine taxa and selected pollen taxa in palynological assemblages from sedimentary rocks hosting $G$. (E.) soltykovensis $(=K$. soltykovensis sensu Gierlinski 1996) tracks in Skåne. The samples are arranged stratigraphically.

Palynology. - Fourteen taxa were identified in Sample 3 (Appendix A). Gymnosperm pollen grains overwhelmingly dominate ( $84 \%$ of total relative abundance) mainly due to the very high counts of Ricciisporites spp. (51\%) and P. elatoides (20\%).

Age. - The sample was dated to Rhaetian based on the anomalously high proportions of Ricciisporites and Perinopollenites, together with the presence of the typical Rhaetian key species L. lundbladii (Fig. 7).

\section{Sample 4 (LO11771t)}

Ichnofossil $G$. (E.) soltykovensis belonging to a theropod dinosaur, set in heterolithic siltstone. The footprint is preserved as a positive-relief hypichnia on the uppermost bedding plane of the siltstone block. Dated to latest Rhaetian based on palynology in this study.

Palynofacies. - Despite the fact that the organic residue in Sample 4 is dominated by wood particles (62\%), pollen and spores collectively make up a relatively high proportion of the sample $(31 \%)$. Charcoal particles were also detected in this sample (2\%; Fig. 5D).

Palynology. - Nineteen palynomorph taxa were identified in Sample 4, all of them are non-marine (Appendix A). Spores dominate, with a relative abundance of $53 \%$, and the main portion is made up by the fern-spore genus Cyathidites $(30 \%)$.
Gymnosperm pollen grains constitute $41 \%$, dominated by taxa belonging to Alisporites (20\%) followed by Ricciisporites (13\%). This sample also contains freshwater algae including Botryococcus braunii (6\%).

Age. - The dating of this sample was somewhat difficult. It differs from the other samples in lacking the gymnosperm pollen $P$. elatoides and also in having a number of freshwater algae. Definite marker species are lacking. Riccisporites attains $11 \%$ and spores reach a high relative abundance of $53 \%$. Based on the palynological assemblage, this sample is tentatively dated as latest Rhaetian - earliest Hettangian correlative with the "Topmost upper Rhaetian" of Lund (1977). This interval is also described in Larsson (2009) from Laröd and Vallåkra in Skåne, and part of the TSI of Larsson (2009).

\section{Sample 5 (LO5463t)}

Ichnofossil $G$. (E.) soltykovensis (Fig. 4) belonging to a theropod dinosaur set in a flaser-bedded siltstone with dark carbonaceous lamina from the Vallåkra quarry (Fig. 3). This ichnofossil was originally described by Gierliński \& Ahlberg (1994) and dated to latest Rhaetian to earliest Hettangian and part of the TSI of Larsson (2009).

Palynofacies. - The microscopic organic matter in this sample is dominated by wood remains $(68 \%)$ followed by miospores (21\%; Fig. 5E, Table 1). AOM is present (3\%) but no marine components were identified. 

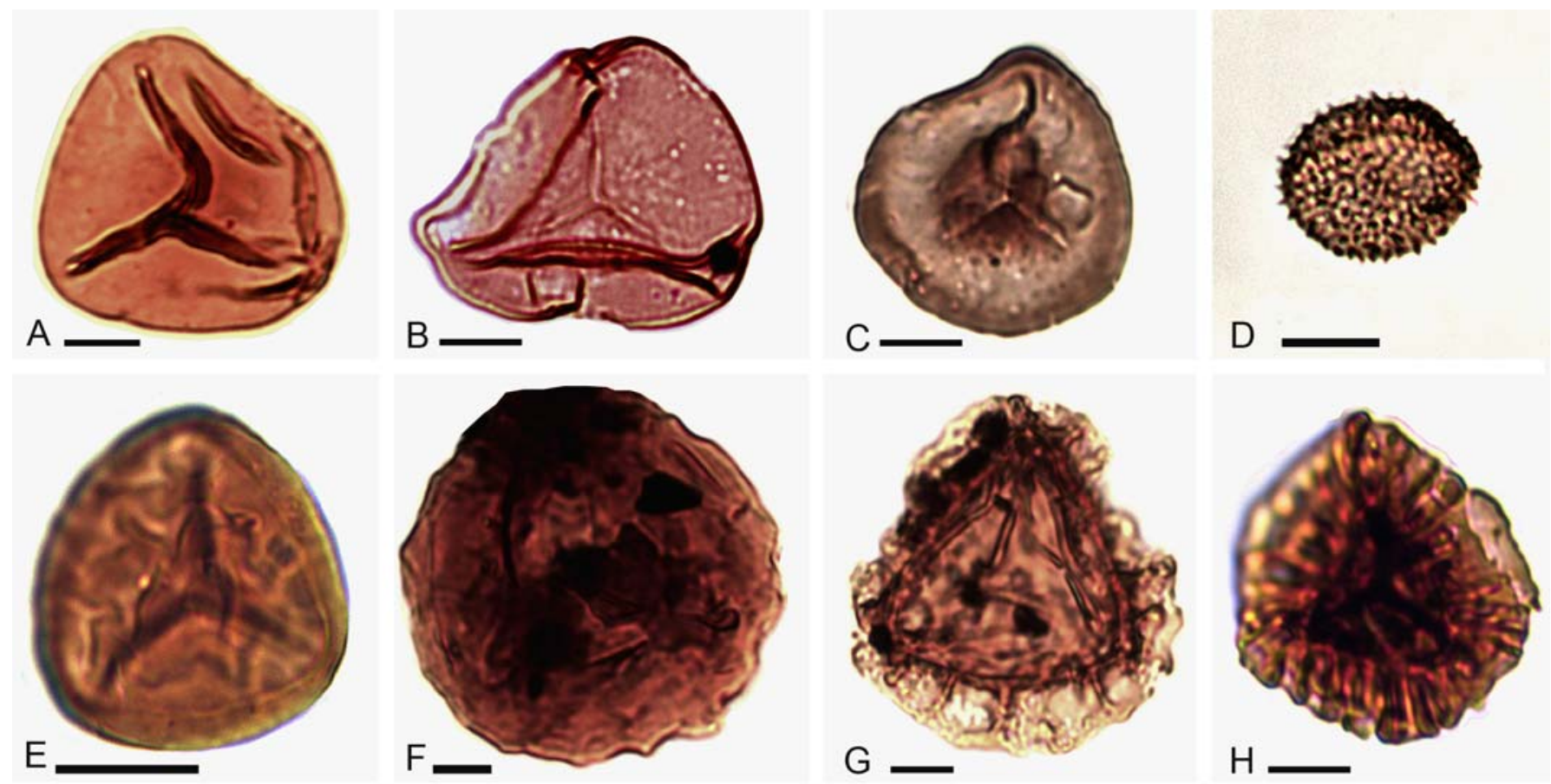

$\mathrm{H}$

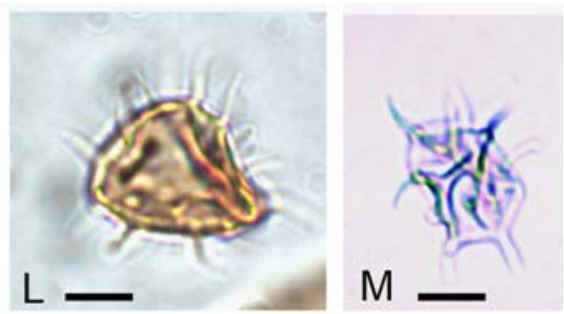

$\mathrm{J}$
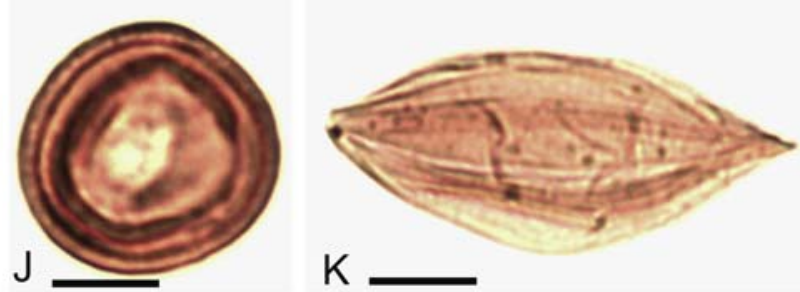

$\mathrm{L}$
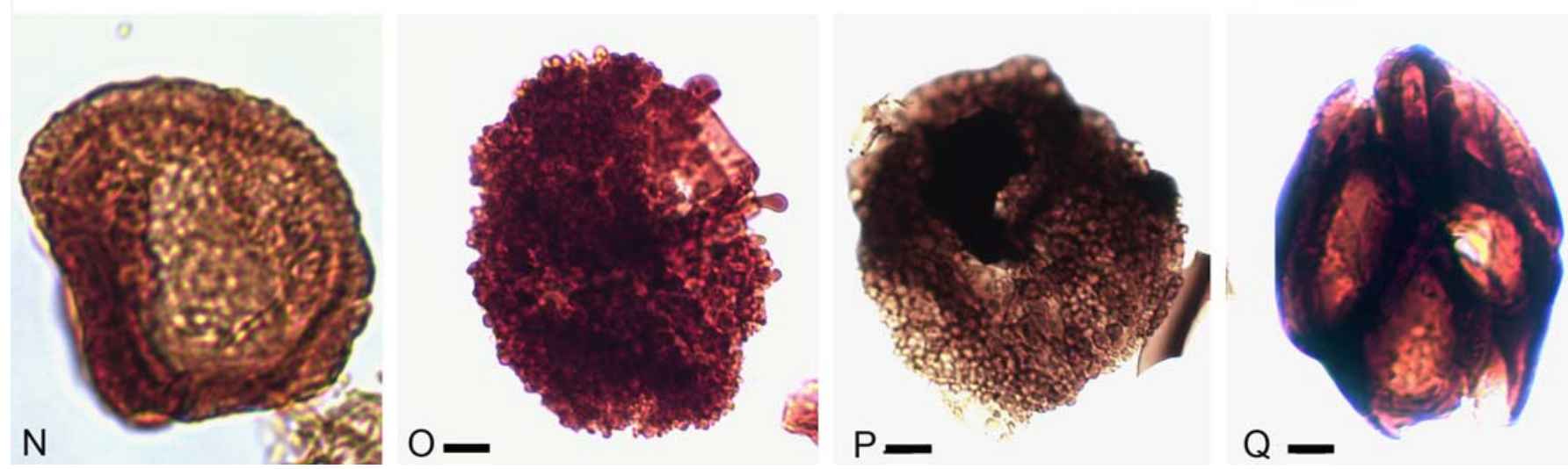

Fig. 7. Light micrographs of representative pollen and spores from the investigated samples, scale bars $=10 \mu \mathrm{m}$. Taxa, sample number and England Finder Reference (EFR) and LO numbers A. C. minor, 1, EFR: P26-2 (LO11710t); B. C. minor, 5, EFR-L28 (LO11711t); C. Annulispora folliculosa, 1, EFR: N36-2 (LO11712t); D. Echinosporis, 2, EFR: U35-2 (LO11713t); E. Z. intercriptus, 1, EFR: R22 (LO11714t); F. Camarozonosporites rudis, 3, EFR: N28-1 (LO11715t); G. L. lundbladii, 1, EFR: J26-1 (LO11716t); H. Limbosporites sp. 3, EFR: M27 (LO11717t); I. Classopollis spp., 2, EFR: H20-3 (LO11718t); J. Classopollis spp., 2, EFR: H31-1 (LO11719t); K. P. elatoides, 2, EFR: P31 (LO11720t); L. Michrystridium sp., 1, EFR: N35-3 (LO11721t); M. Michrystridium sp. 1, EFR: M33-2, (LO11722t); N. Q. anellaeformis, 3, EFR: N31-3 (LO11723t); O-P. R. tuberculatus, 3, EFR: U46-4 (LO11724t); Q. Ricciisporites sp. 1, 3, EFR: L30 (LO11725t).

Palynology. - In this palynological assemblage, 17 species of pollen and spores and one freshwater alga were identified (Appendix A). Spores represent $48 \%$ of the assemblage, whereas gymnosperm pollen grains comprise $50 \%$ (Appendix A). This assemblage is non-marine. The spores are dominated by fern spores which in turn are strongly dominated by the spore genera Cyathidites (27\%) and Deltoidospora (10\%). Lycophyte spores reach a relative abundance of $2 \%$ and bryophytes spores reach $3 \%$. The gymnosperms are dominated by Ricciisporites together with Alisporites and P. elatoides (Figs. 6 and 7; Appendix A).

Age. - Important key species include L. lundbladii and, based on the abundance of Ricciisporites, $P$. elatoides and Pinuspollenites minimus, Sample 5 is interpreted to be spanning the $\mathrm{Tr}-\mathrm{J}$ 
boundary. The palynological composition of this transitional zone agrees very well with the TSI of Larsson (2009).

\section{Discussion and conclusions}

Five theropod dinosaur ichnofossils attributed to $G$. (E.) soltykovensis ( $=K$. soltykovensis) by Gierliński \& Ahlberg (1994) were investigated by sampling the host sediments for palynological assemblages.

The ichnofossils were all dated to an interval spanning the $\mathrm{Tr}-$ J boundary (Table 1, Fig. 6). Of these, two were attributed to the late Rhaetian, and two to the $\mathrm{Tr}-\mathrm{J}$ boundary interval, the socalled TSI of Larsson (2009; Fig. 6). Specimen (LO11768t) was dated as earliest Hettangian based on the presence of key Jurassic spore-pollen taxa and high portions of $P$. minimus in the host sediments. The extremely high relative abundance of the pollen $R$. tuberculatus in Sample 3 (LO11770t) may partly reflect taphonomic sorting as this footprint is a hypichnia, a sediment sheet infilling the trace. These sediments were possibly deposited under higher energy environments during more rapid sedimentation than the finer grained sediments constituting the other specimens. Under these circumstances, more buoyant pollen, such as $R$. tuberculatus, may have been transported longer distances and winnowed into greater concentrations.

Our new biostratigraphical data thus resolve the age of these sediments previously dated to the earliest Jurassic based on lithostratigraphy, and show that the heterolithic mudstone in the southern wall of the Vallåkra quarry is positioned stratigraphically below the Boserup beds. Since first described by Welles (1971), Kayentapus (Grallator (Eubrontes) sp. sensu Gierlinski 1991; see Gierlinski 1996) has become one of the most widely recognized Early Jurassic theropod track ichnogenera. According to new palynological studies present in this paper, it may occur also in the uppermost Triassic deposits.

The palynofacies analysis reveals an organic content dominated by phytoclasts (wood remains and plant cuticles; Fig. 5). The sediment bearing the basal Jurassic ichnofossil shows evidence of marine elements and a high proportion of AOM (Fig. 5A) that attests to deposition within a paralic, probably tidal, environment. These sediments further include significant proportions of charcoal particles transported from hinterland areas.

On the basis of this palynological study, we conclude that the vegetation was primarily composed of a range of ground ferns with a canopy of Cupressaceae (cypress), seed ferns and minor portions of Podocarpaceae, Araucariaceae and, in the younger sediments, also Pinaceae. The conifer producing the "disaster taxon" $R$. tuberculatus was abundant in the late Rhaetian ecosystem signalling abnormal environmental conditions. The volcanic activity in the Central Atlantic Magmatic Province (CAMP) has been proposed as one of the major causes behind the Tr-J extinction (e.g. Wignall 2001; Marzoli et al. 2004; Hesselbo et al. 2007; Schaltegger et al. 2008; van de Schootbrugge et al. 2009) with rapid global warming (Wignall 2005) and increased fire activity (Belcher et al. 2010). The CAMP flood basalts were most probably the main factor influencing the European floras, providing conditions that in some way were advantageous for the plants producing Ricciisporties. However, as its systematic affinities are as yet unresolved, we can only speculate which specific factors connected to CAMP that made it possible for the "Ricciisporites plants" to proliferate and the species warrants further study.
Acknowledgements. - The authors thank Drs G. Niedźwiedzki and S. Poropat for their valuable review with extensive feedback which unquestionably improved our paper. The authors would like to thank an anonymous reviewer for comments on the palynology. This research was supported by the Swedish Research Council under Grant LUCCI (Lund University Carbon Cycle Centre) to V. Vajda and Grant 621-2011-4922 to M. Calner. V. University Carbon Cycle Centre) to V. Vajda and Grant 621-2011-4922 to M. Calner. V.
Vajda is a Royal Swedish Academy of Sciences Research Fellow funded through the Knut and Alice Wallenberg Foundation. Andrea Santivanez is thanked for taking the pollen micrographs and Russ Harms GeoLab Ltd for palynological processing.

\section{References}

Ahlberg, A., Arndorff, L. \& Guy-Ohlson, D., 2002: Onshore climate change during the Late Triassic marine inundation of the Central European Basin. Terra Nova 14 (4), 241-248.

Ahlberg, A., Olsson, I. \& Simkevicius, P.S., 2003b: Triassic-Jurassic weathering and clay mineral dispersal in basement areas and sedimentary basins of southern Sweden. Sedimentary Geology 161, 15-29.

Ahlberg, A. \& Siverson, M., 1991: Early Jurassic dinosaur footprints in Helsingborg, southern Sweden. Geologiska Föreningens $i$ Stockholm Förhandlingar 113, 339-340.

Ahlberg, A., Sivhed, U. \& Erlström, M., 2003a: The Jurassic of Skåne, southern Sweden. In J.R. Ineson \& F. Surlyk (eds.): The Jurassic of Denmark and Greenland, . Geological Survey of Denmark and Greenland Bulletin 1, 527-541.

Akikuni, K., Hori, R., Vajda, V., Grant-Mackie, J. \& Ikehara, M., 2010 Stratigraphy of Triassic-Jurassic boundary sequences from the Kawhia coast and Awakino gorge, Murihiku Terrane, New Zealand. Stratigraphy 7, 7-24.

Anderson, J.M., Anderson, H.M., Archangelsky, S., Bamford, M., Chandra, S., Dettmann, M.E., Hill, R.S., McLoughlin, S. \& Rösler, O., 1999: Patterns of Gondwana plant colonisation and diversification. African Journal of Earth Sciences 28, 145-167.

Andréasson, P.G., 2006: Geobiosfären-en introduktion, Studentlitteratur.

Batten, D.J., 1996: Palynofacies and palaeoenvironmental interpretation, Chapter 26A. In J. Jansonius \& D.C. McGregor (eds.): Palynology: Principles and Applications 3, 1011-1164. American Association of Stratigraphic Palynologists Foundation, Dallas.

Belcher, C.M., Mander, L., Rein, G., Jervis, F.X, Haworth, M., Hesselbo, S.P Glasspool, I.J. \& McElwain, J.C., 2010: Increased fire activity at the Triassic/Jurassic boundary in Greenland due to climate-driven floral change. Nature Geoscience 3, 426-429.

Bölau, E., 1952: Neue Fossilfunde aus dem Rhät Schönens und ihre paläogeographish-Ökologische Auswartung. Geologiska Föreningens $i$ Stockholm Förhandlingar 74, 44-50.

Bonis, N.R., Kürschner, W.M. \& Krystyn, L., 2009: A detailed palynological study of the Triassic-Jurassic transition in key sections of the Eiberg Basin (Northern Calcareous Alps, Austria). Review of Palaeobotany and Palynology $156,376-400$

Brusatte, S.L., Nesbitt, S.J., Irmis, R.B., Butler, R.J., Benton, M.J. \& Norell, M.A., 2010: The origin and early radiation of dinosaurs. Earth-Science Reviews 101, 68-100.

Deenen, M.H.L., Ruhl, M., Bonis, N.R., Krijgsman, W., Kuerschner, W.M. Reitsma, M. \& Van Bergen, M.J., 2010: A new chronology for the endTriassic mass extinction. Earth and Planetary Science Letters 291, 113-125.

Dybkjær, K., 1991: Palynological zonation and palynofacies investigation of the Fjerritslev Formation (Lower Jurassic-basal Middle Jurassic) in the Danish Subbasin. Danmarks og Geologiske Unders $\phi g e l s e$ Series A 30, 4-150.

Fowell, S.J. \& Olsen, P.E., 1993: Time calibration of Triassic/Jurassic microfloral turnover, eastern North America. Tectonophysics 222, 361-369.

Gierliński, G., 1991: New dinosaur ichnotaxa from the Early Jurassic of the Holy Cross Mountains, Poland. Palaeogeography, Palaeoclimatology, Palaeoecology 85 (1), 137-148.

Gierliński, G., 1996: Dinosaur ichnotaxa from the Lower Jurassic of Hungary. Geological Quarterly 40, 119-128.

Gierliński, G. \& Ahlberg, A., 1994: Late Triassic and Early Jurassic dinosaur footprints in the Höganäs Formation of southern Sweden. Ichnos 3, 99-105.

Gorzelak, P., Niedźwiedzki, G. \& Skawina, A., 2010: Pathologies of non-marine bivalve shells from the Late Triassic of Poland. Lethaia 43, 285-289.

Götz, A.E., Ruckwied, K., Pálfy, J. \& Haas, J., 2009: Palynological evidence of synchronous changes within the terrestrial and marine realm at the Triassic/Jurassic boundary (Csővár section, Hungary). Review of Palaeobotany and Palynology 156, 401-409.

Guy-Ohlson, D., 1981: Rhaeto-Liassic palynostratigraphy of the Valhall bore No. 1 Scania. Geologiska Föreningens $i$ Stockholm Förhandlingar 103, $233-248$

Hallam, A., 2002: How catastrophic was the end-Triassic mass extinction event? Lethaia 35, 147-157.

Halle, T.G., 1908: Zur Kenntnis der mesozoischen Equisetales Schwedens. Kungliga Svenska Vetenskapsakademiens Handlingar 43, 1-56.

Harris, T.M., 1931: Rhaetian floras. Biological Reviews 6, 133-162.

Haubold, H., 1986: Archosaur footprints at the terrestrial Triassic-Jurassic transition. In K. Padian (ed.): The Beginning of the Age of Dinosaurs: Faunal Change Across the Triassic-Jurassic Boundary, 189-201. Cambridge University Press, Cambridge.

Hermelin, S.G., 1773: Anmärkningar om Boserups stenkols-grufva och de öfrige stenkols-försök uti Skåne. Kungliga Svenska Vetenskapsakademiens Handlingar 34, 236-254. 
Hesselbo, S.P., McRoberts, C.A. \& Pálfy, J., 2007: Triassic-Jurassic boundary events: Problems, progress, possibilities. Palaeogeography, Palaeoclimatology, Palaeoecology 244, 1-10.

Hesselbo, S.P., Robinson, S.A., Syrluk, F. \& Piasecki, S., 2002: Terrestrial and marine extinction at the Triassic-Jurassic boundary synchronised with major carbon-cycle perturbation: a link to initiation of massive volcanism. Geology $30,251-254$.

Jansson, I.-M., McLoughlin, S. \& Vajda, V., 2008a: Early Jurassic annelid cocoons from eastern Australia. Alcheringa 32, 285-296.

Jansson, I.-M., McLoughlin, S., Vajda, V. \& Pole, M., 2008b: An Early Jurassic flora from the Clarence-Moreton Basin, Australia. Review of Palaeobotany and Palynology 150, 5-21.

Johansson, N., 1922: Die rhätische Flora der Kohlengruben bei Stabbarp und Skromberga in Schonen. Kungliga Svenska Vetenskapsakademiens Handlingar 63, 1-78.

Koppelhus, E.B. \& Nielsen, L.H., 1994: Palynostratigraphy and palaeoenvironments of the Lower to Middle Jurassic Bagå Formation of Bornholm, Denmark. Palynology 18, 139-194.

Kürschner, W.M., Bonis, N.R. \& Krystyn, L., 2007: Carbon-isotope stratigraphy and palynostratigraphy of the Triassic-Jurassic transition in the Tiefengraben section - Northern Calcareous Alps (Austria). Palaeogeography, Palaeoclimatology, Palaeoecology 244, 257-280.

Larsson, L.M., 2009: Palynostratigraphy of the Triassic-Jurassic transition in southern Sweden. GFF 131, 147-163

Larsson, K., Solakius, N. \& Vajda, V., 2000: Foraminifera and palynomorphs from the greensand-limestone sequences (Aptian-Coniacian) in southwestern Sweden. Geologische Jahrbuch fur Geologie und Paläontologie 216, 277-312.

Lindström, S. \& Erlström, M., 2006: The late Rhaetian transgression in southern Sweden: Regional (and global) recognition and relation to the TriassicJurassic boundary. Palaeogeography, Palaeoclimatology, Palaeoecology 241, 339-372

Lockley, M.G., Gierliński, G.D. \& Lucas, S.G., 2011: Kayentapus revisited: notes on the type material and the importance of this theropod footprint ichno-genus. New Mexico Museum of Natural History and Science Bulletin 53, 330-336.

Lucas, S.G., Klein, H., Lockley, M.G., Spielmann, J.A., Gierlinski, G., Hunt, A.P. \& Tanner, L.H., 2006: Triassic-Jurassic stratigraphic distribution of the theropod footprint ichnogenus Eubrontes. New Mexico Museum of Natural History and Science, Bulletin 37, 86-93.

Lund, J.J., 1977: Rhaetic to Lower Liassic palynology of the onshore southeastern North Sea Basin. Danmarks og Geologiske Undersøgelse 109, 1-129.

Lundblad, A.B., 1950: Studies in the Rhaeto-Liassic floras of Sweden. I. Pteridophyta, Pteridospermae and Cycadophyta from the mining district of NW Scania. Kungliga Svenska Vetenskapsakademiens Handlingar, Fjärde Serien 1, 1-82.

Lundblad, A.B., 1959a: Studies in the Rhaeto-Liassic floras of Sweden. II. Ginkgophyta from the mining district of NW Scania. Kungliga Svenska Vetenskapsakademiens Handlingar, Fjärde Serien 6, 1-38.

Lundblad, A.B., 1959b: Rhaeto-Liassic floras and their bearing on the stratigraphy of Triassic-Jurassic rocks. Stockholm Contributions in Geology 3, 83-102.

Lundblad, B., 1949: De geologiska resultaten från borrningarna vid Höllviken. Del 4. On the presence of Lepidopteris in cores from "Höllviken II". Sveriges Geologiska Undersökning, Serie C 507, Arsbok 43, 1-11.

Mander, L., Collinson, M.E., Chaloner, W.G., Brain, A.P.R. \& Long, D.G., 2012: The ultrastructure and botanical affinity of the problematic mid-Mesozoic palynomorph Ricciisporites tuberculatus Lundblad. International Journal of Plant Sciences 173 (4), 429-440.

Mander, L., Kürschner, W.M., \& McElwain, J.C., 2013: Palynostratigraphy and vegetation history of the Triassic-Jurassic transition in East Greenland. Journal of the Geological Society 170, 37-46.

Marzoli, A., Bertrand, H., Knight, K.B., Cirilli, S., Buratti, N., Vérati, C., Nomade, S., Renne, P.R., Youbi, N., Martini, R., Allenbach, K., Neuwerth, R., Rapaille, C., Zaninetti, L. \& Bellieni, G., 2004: Synchrony of the Central Atlantic magmatic province and the Triassic-Jurassic boundary climatic and biotic crisis. Geology 32, 973-976.

McElwain, J.C., Wagner, P.J. \& Hesselbo, S.P., 2009: Fossil plant relative abundances indicate sudden loss of Late Triassic biodiversity in East Greenland. Science 324, 1554-1556.

McLoughlin, S. \& Vajda, V., 2013: Gingko forests and tsunamis in the Swedish countryside. Deposits Magazine 33, 20-22.

Mehlqvist, K., Vajda, V. \& Larsson, L., 2009: An assemblage of a Middle Jurassic flora from Bornholm, Denmark - a study of a historic collection at Lund University, Sweden. GFF 131, 137-146.

Meyer, C.A., Hippler, D. \& Lockley, M.G., 2001: The Late Cretaceous vertebrate ichnofacies of Bolivia - facts and implications. Asociación Paleontológica Argentina - Publicación Especial 7, 133-138.

Nathorst, A.G., 1878: Om floran i Skånes kolförande bildningar. Sveriges Geologiska Undersökning, Serie C 27, 1-52.

Nathorst, A.G., 1879: Om floran i Skånes kolförande bildningar I. Floran vid Bjuf. Sveriges Geologiska Undersökning C33, 1-52.

Niedźwiedzki, G., 2011: A Late Triassic dinosaur-dominated ichnofauna from the Tomanová Formation of the Tatra Mountains, Central Europe. Acta Palaeontologica Polonica 56 (2), 291-300.

Niedźwiedzki, G., Sulej, T. \& Dzik, J., 2012: A large predatory archosaur from the Late Triassic of Poland. Acta Palaeontologica Polonica 57 (2), 267-276.
Norin, R., 1949: Studie över den mineralogiska sammansättningen av några lertyper från NV Skånes rät-lias, Vallåkra och Kågerödsbildningar. Geologiska Föreningens $i$ Stockholm Förhandlingar 71, 215-237.

Norling, E., 1990: Lagerföljd och bergarter. In E. Norling \& H. Wikman (eds.): Beskrivning till bergrundskartan Höganäs NO/Helsingborg NV. Sveriges Geologiska Undersökning Af 129, 60-84.

Norling, E., Ahlberg, A., Erlström, M. \& Sivhed, U., 1993: Guide to the Upper Triassic and Jurassic geology of Sweden. Sveriges Geologiska Undersökning Ca 82, 71 .

Ocampo, A., Vajda, V. \& Buffetaut, E., 2006: Unravelling the CretaceousPaleogene (KT) Turnover, Evidence from Flora, Fauna and Geology. In Biological processes associated with impact events, 197-219. Springer, Berlin Heidelberg.

Olsen, P.E., 1980: Fossil great lakes of the Newark Supergroup in New Jersey. In W. Manspeizer (ed.): Field Studies in New Jersey Geology and Guide to Field Trips, 52nd Ann. Mtg. New York State Geology Association, Newark College of Arts and Sciences, Newark, Rutgers University, p. 352-398.

Olsen, P.E., Kent, D.V., Sues, H.-D., Koeberl, C., Huber, H., Montanari, A., Rainforth, E.C., Fowell, S.J., Szajna, M.J. \& Hartline, B.W., 2002: Ascent of Dinosaurs Linked to an Iridium Anomaly at the Triassic-Jurassic Boundary. Science 296, 1305-1307.

Olsen, P.E., Smith, J.B. \& McDonald, N.G., 1998: Type material of the type species of the classic theropod footprint genera Eubrontes, Anchisauripus, and Grallator (Early Jurassic, Hartford and Deerfield basins, Connecticut and Massachusetts, U.S.A.). Journal of Vertebrate Paleontology 18, 586-601.

Pedersen, K.R. \& Lund, J.J., 1980: Palynology of the plant-bearing Rhaetian to Hettangian Kap Stewart Formation, Scoresby Sund, East Greenland. Review of Palaeobotany and Palynology 31, 1-69.

Pieńkowski, G., 1991a: Sedimentology of the Hettangian and Sinemurian deposits from the Helsingborg area, Scania, Southern Sweden. Facies 24, 39-86.

Pieńkowski, G., 1991b: Eustatically-controlled sedimentation in the HettangianSinemurian of Poland and Sweden. Sedimentology 38, 503-518.

Pieńkowski, G., Niedźwiedzki, G. \& Waksmundzka, M., 2012: Sedimentological, palynological, and geochemical studies of the terrestrial Triassic-Jurassic boundary in north-western Poland. Geological Magazine 149, 308-332.

Pleijel, C., 1975: Nya dinosauriefotspår från Skånes Rät-Lias. Fauna och Flora 3, 116-120.

Pott, C. \& McLoughlin, S., 2009: Bennettitalean foliage in the RhaetianBajocian (latest Triassic-Middle Jurassic) floras of Scania, southern Sweden. Review of Palaeobotany and Palynology 158, 117-166.

Pott, C. \& McLoughlin, S., 2011: The Rhaetian flora of Rögla, northern Scania, Sweden. Palaeontology 54, 1025-1051.

Rainforth, E.C., 2005: Ichnotaxonomy of the fossil footprints of the Connecticut Valley (Early Jurassic, Newark Supergroup, Connecticut and Massachusetts), [Ph.D. dissertation]. New York, Columbia University, 1301 pp.

Raup, D.M. \& Sepkoski, J.J., 1982: Mass extinctions in the marine fossil record. Science 215, 1501-1503.

Ruhl, M., Kürschner, W.M. \& Krystyn, L., 2009: Triassic-Jurassic organic carbon isotope stratigraphy of key sections in the western Tethys realm (Austria). Earth and Planetary Science Letters 281, 169-187.

Schaltegger, U., Guex, J., Bartolini, A., Schoene, B. \& Ovtcharova, M., 2008: Precise $\mathrm{U}-\mathrm{Pb}$ age constraints for end-Triassic mass extinction, its correlation to volcanism and Hettangian post-extinction recovery. Earth and Planetary Science Letters 267, 266-275.

Schulte, P., Alegret, L., Arenillas, I., Arz, J.A., Barton, P.J., Bown, P.R., Bralower, T., Christeson, G., Claeys, P., Cockell, C., Collins, G., Deutsch, A., Goldin, T., Goto, K., Grajales-Nishimura, J.M., Grieve, R., Gulick, S., Johnson, K.R., Kiessling, W., Koeberl, C., Kring, D.A., MacLeod, K.G., Matsui, T., Melosh, J., Montanari, A., Morgan, J., Neal, C., Norris, R.D., Pierazzo, E., Ravizza, G., Rebolledo-Vieyra, M., Reimold, W-U., Robin, E., Salge, T., Speijer, R.P., Sweet, A.R., Urrutia-Fucugauchi, J., Vajda, V., Whalen, M.T., Willumsen, P.S., 2010a: The Chicxulub impact and the mass extinction at the CretaceousPaleogene boundary. Science 327, 1214-1218 (41 authors).

Schulte, P., Alegret, L., Arenillas, I., Arz, J.A., Barton, P.J., Bown, P.R., Bralower, T., Christeson, G., Claeys, P., Cockell, C., Collins, G., Deutsch, A., Goldin, T., Goto, K., Grajales-Nishimura, J.M., Grieve, R., Gulick, S., Johnson, K.R., Kiessling, W., Koeberl, C., Kring, D.A., MacLeod, K.G., Matsui, T., Melosh, J., Montanari, A., Morgan, J., Neal, C., Norris, R.D., Pierazzo, E., Ravizza, G., Rebolledo-Vieyra, M., Reimold, W-U., Robin, E., Salge, T., Speijer, R.P., Sweet, A.R., Urrutia-Fucugauchi, J., Vajda, V., Whalen, M.T., Willumsen, P.S., 2010b: Reply - the Chicxulub impact and the mass extinction at the Cretaceous-Paleogene boundary. Science 328, 975-976 (41 authors).

Sha, J., Vajda, V., Pan, Y., Larsson, L., Yao, X., Zhang, X., Wang, Y., Cheng, X. \& Jiang, B., 2011: Stratigraphy of the Triassic-Jurassic boundary successions of the Southern Margin of the Junggar Basin, Northwestern China. Acta Geologica Sinica 85, 801-840.

Sivhed, U., 1984: Litho- and biostratigraphy of the Upper Triassic-Middle Jurassic in Scania, Southern Sweden. Sveriges Geologiska Undersökning C $806,31$.

Steinthorsdottir, M., Jeram, A.J. \& McElwain, J.C., 2011: Extremely elevated $\mathrm{CO}_{2}$ concentrations at the Triassic/Jurassic boundary. Palaeogeography, Palaeoclimatology, Palaeoecology 308, 418-432.

Thulborn, R.A., 2013: Lark Quarry revisited: a critique of methods used to identify a large dinosaurian track-maker in the Winton Formation (AlbianCenomanian), western Queensland, Australia. Alcheringa DOI:10.1080/ 03115518.2013 .748482 
Troedsson, G., 1943: Om gränsen mellan rät och lias i Skåne. Geologiska Föreningens $i$ Stockholm Förhandlingar 65, 271-284.

Troedsson, G., 1951: On the Höganäs Series of Sweden (Rhaeto-Lias). Skrifter från Mineralogisk- och Paleontologisk-Geologiska Institutionerna Lund 7, 269.

Turner, S., Bean, L.B., Dettmann, M., McKellar, J.L., McLoughlin, S. \& Thulborn, T., 2009: Australian Jurassic sedimentary and fossil successions: current work and future prospects for marine and non-marine correlation. GFF 131, 49-70.

Vajda, V., 2001: Aalenian to Cenomanian palynofloras of SW Scania, Sweden. Acta Palaeontologica Polonica 46, 403-426.

Vajda, V., 2008: Jurassic - climate and biodiversity. Episodes 31, 436-437.

Vajda, V. \& Raine, J.I., 2010: A palynological investigation of plesiosaurbearing rocks from the Upper Cretaceous Tahora Formation, Mangahouanga, New Zealand. Alcheringa 34 (3), 359-374.

Vajda, V. \& Wigforss-Lange, J., 2006: The Jurassic-Cretaceous transition of Southern Sweden - palynological and sedimentological interpretation. Progress in Natural Science 16, 1-38.
Vajda, V. \& Wigforss-Lange, J., 2009: Onshore Jurassic of Scandinavia and related areas. GFF $131,5-23$.

van de Schootbrugge, B., Quan, T.M., Lindström, S., Püttmann, W., Heunisch, C., Pross, J., Fiebig, J., Petschick, R., Röhling, H.-G., Richoz, S., Rosenthal, Y. \& Falkowski, P.G., 2009: Floral changes across the Triassic/Jurassic boundary linked to flood basalt volcanism. Nature Geoscience 2, 589-594.

Welles, S.P., 1971: Dinosaur footprints from the Kayenta Formation of northern Arizona. Plateau 44 (1), 27-38.

Wigforss-Lange, J., Vajda, V. \& Ocampo, A., 2007: Trace element concentrations in the Mexico-Belize ejecta layer: a link between the Chicxulub impact and the global Cretaceous-Paleogene boundary. Meteoritics and Planetary Science 42, 1871-1882.

Wignall, P.B., 2001: Large igneous provinces and mass extinctions. EarthScience Reviews 53, 1-33.

Wignall, P.B., 2005: The link between large igneous province eruptions and mass extinctions. Elements 1, 293-297.

Zhou, Z., 1995: Jurassic floras. In X. Li (ed.): Fossil Floras of China Through the Geological Ages, 343-410. Guandong Science and Technology Press, Guangzhou.

\section{Appendix A: Quantitative palynological data.}

\begin{tabular}{|c|c|c|c|c|c|}
\hline Dinosaur footprint & 1 (LO11768t) & 2 (LO11769t) & 3 (LO11770t) & 4 (LO11771t) & 5 (LO5463t) \\
\hline Number of taxa & 25 & 12 & 14 & 19 & 18 \\
\hline Filicophyta (ferns) & & & & & \\
\hline Acanthotriletes varius & 1 & & 1 & & \\
\hline Baculatisporites comaumensis & 1 & & 2 & & 2 \\
\hline Cibotiumspora juriensis & 1 & & & & \\
\hline Cyathidites australis & & 7 & & 2 & 6 \\
\hline Cyathidites minor & 36 & 5 & 6 & 28 & 21 \\
\hline Deltoidospora sp. & & & & 14 & 10 \\
\hline Gleicheniidites senonicus & 4 & 5 & & & 5 \\
\hline Peromonolites densus & & 2 & 1 & & \\
\hline Striatella seebergensis & 1 & & & 1 & \\
\hline Todisporites major & 1 & & & & \\
\hline Todisporites minor & 1 & & & & \\
\hline Total ferns (\%) & 44 & 19 & 11 & 45 & 44 \\
\hline \multicolumn{6}{|l|}{ Lycophyta (club mosses) } \\
\hline Camarozonosporites rudis & & & 1 & 1 & 0.5 \\
\hline Klukisporites neovariegatus & 1 & & & & \\
\hline Limbosporites lundbladi & & 12 & 2 & & 0.5 \\
\hline Lycopodiumsporites sp. & 1 & & & & 1 \\
\hline Lycopodiumsporites clavatoides & & & & 1 & \\
\hline Retitriletes austroclavatidites & 1 & 2 & & & \\
\hline Retitriletes semimuris & 1 & & & & \\
\hline Zebrasporites intercriptus & 1 & & & 1 & \\
\hline Total club mosses (\%) & 5 & 14 & 4 & 3 & 2 \\
\hline \multicolumn{6}{|l|}{ Bryophyta (mosses) } \\
\hline Annulispora folliculosa & 1 & & & & 1 \\
\hline Cingutriletes clavus & 1 & & & 1 & \\
\hline Densoisporites psilatus & & 2 & & & \\
\hline Stereisporites antiquasporis & 1 & & 2 & 4 & 2 \\
\hline Total mosses $(\%)$ & 2 & 2 & 2 & 5 & 3 \\
\hline Total spores (\%) & 51 & 35 & 16 & 53 & 49 \\
\hline \multicolumn{6}{|l|}{ Gymnosperma } \\
\hline Alisporites parvus & 8 & 2 & 2 & 20 & 11 \\
\hline Araucariacites australis & 2 & & & 1 & 6 \\
\hline Classopollis spp. & 5 & 5 & 6 & 2 & 3 \\
\hline Cycadopites sp. & & & 1 & & \\
\hline Perinopollenites elatoides & 7 & 35 & 20 & & 10 \\
\hline Pinuspollenites sp. & 10 & & & 1 & 4 \\
\hline Podocarpidites sp. & 1 & 5 & 1 & 1 & 3 \\
\hline Quadraeculina annelaeformis & 5 & & 2 & 2 & \\
\hline Ricciisporites spp. & 11 & 19 & 51 & 13 & 13 \\
\hline Vitreisporites bjuvensis & & & & 1 & \\
\hline Total pollen (\%) & 47 & 65 & 84 & 41 & 50 \\
\hline \multicolumn{6}{|l|}{ Others } \\
\hline Michrystridium spp. & 2 & & & & \\
\hline Freshwater algae & & & & 4 & 1 \\
\hline Botryococcus braunii & & & & 2 & \\
\hline Total marine/freshwater taxa (\%) & 2 & & & 6 & 1 \\
\hline All palynomorphs & 100 & 100 & 100 & 100 & 100 \\
\hline
\end{tabular}

Note: Numbers represent the relative abundance in percentages for each taxon. 